О. С. щуР, аспірант кафедри грунтознавства та географії грунтів (Львівський національний університет імені Івана Франка), shchur7555-1@murdoch.in, https://orcid.org/0000-0002-1690-5838
O. SHCHUR, PhD student at the Department of Soil Science and Soil Geography (Ivan Franko National University of Lviv), shchur7555-1@murdoch.in, https://orcid.org/0000-0002-1690-5838

\title{
МОРФОЛОГІЧНІ ОСОБЛИВОСТІ ЗАЛИШКОВО-КАРБОНАТНИХ ЧОРНОЗЕМІВ НА ЕЛЮВІЇ ЩІЛЬНИХ КАРБОНАТНИХ ПОРІД МАЛОГО ПОЛІССЯ
}

\author{
MORPHOLOGICAL FEATURES OFRESIDUAL CARBONATE CHERNOZEMS ON THE ELUVIUM \\ OF DENSE CARBONATE ROCKS OF THE MALE POLISSIA \\ 3 нагоди 360-річчя від дня заснування Львівського \\ національного університету імені Івана Франка
}

\begin{abstract}
Актуальність наукового дослідження визначається недостатньою вивченістю питань, пов'язаних з морфологічними особливостями залишкових карбонатних чорноземів, а також браком наукових публікацій, що якісно висвітлюють різні аспекти складу грунтів Малого Полісся. У цій праці маємо на меті, грунтуючись на основі морфології залишково-карбонатних чорноземів на елювії щільних карбонатних порід Малого Полісся визначити головні особливості складу грунтів цього регіону і його місце в єдиній системі родючих грунтів країни загалом. В основі методології дослідження - поєднання методів системного наукового аналізу складу грунтів регіону Малого Полісся, що дає змогу визначити закономірності поширення грунтів і з'ясувати їхній морфологічний склад, а також морфологічні особливості залишково-карбонатних чорноземів на елювії щільних карбонатних порід Малого Полісся. Дослідження свідчить про істотну важливість вивчення процесів грунтоутворення і вивітрювання грунтів з погляду перспектив сільськогосподарського використання та збереження грунтового ресурсу країни. Результати та висновки цієї праці мають істотне наукове, теоретичне й прикладне значення для подальшого вивчення якості складу грунтів України загалом і Малого Полісся зокрема, для розуміння структури грунтового покриву досліджуваних регіонів і доцільності наукового розроблення методів їхнього використання для потреб народного господарства.
\end{abstract}

Ключові слова: морфологічні особливості, чорноземи карбонатні, елювій карбонатних порід, Мале Полісся, склад грунтів, родючість грунтів.

The relevance of the stated topic of scientific research is determined by the poor knowledge of issues related to the morphological features of residual carbonate chernozems, as well as the lack of scientific publications that qualitatively highlight various aspects of the soil composition of Male Polissia. The main purpose of this research work is to study the morphology of residual-carbonate chernozems on the eluvium of dense carbonate rocks of Male Polissia, in order to determine the main features of the soil composition of this region and its place in the unified system of fertile soils of the country as a whole. The basis of the methodology of this research work is a combination of methods for systematic scientific research of the soil composition of the Male Polissia region as a whole, which makes it possible to determine the main regularities in the distribution of soils in this region and their morphological composition, with an analytical study of the morphological features of residual-carbonate chernozems on the eluvium of dense carbonate rocks of the Male Polissia, which makes it possible to form a structured picture of scientific research of all issues submitted for consideration with a competent arrangement of all the accents of scientific research. The results of this scientific study indicate the essential importance of studying the processes of soil formation and weathering of soils from the point of view of analyzing the prospects for their agricultural use and preserving the soil resource from the wound as a whole. The results and conclusions of this research work are of significant scientific, theoretical and applied significance from the point of view of the prospects for further scientific research in the direction of studying the quality of the soil composition of Ukraine in general and Male Polissia in particular, which is of great importance for understanding the structure of the soil cover of the studied regions. and the expediency of scientific development of methods for their further competent practical use for the needs of the national economy.

Keywords: morphological features, carbonate chernozems, eluvium of carbonate rocks, Male Polissia, soil composition, soil fertility.

\section{Вступ}

Мале Полісся - своєрідна за генезисом (рівнинні територіi, переважне поширення алювіальних і флювіогляціальних пісків серед мергелів як корінних порід, розвинена гідрографічна мережа із заболоченими заплавами, лісовий тип рослинності на тлі лісостепового характеру клімату) територія в південно-західній частині зони мішаних лісів України, що розділяє Волинську й Подільську височини. Ця фізико-географічна область складається з Надбужанської котловини, Бродівської (Крем'янецько-Дубнівської) рівнини і Острозької долини, геоморфологічно добре виражена і розміщується між Волинським і Ростоцько-Опільським грунтовогеографічним краєм широколистої лісової зони України. На півдні, крутим уступом заввишки 150-180 м, Мале Полісся різко переходить у Подільську височину [11].

За адміністративно-територіальним поділом територія Малого Полісся розміщується в межах Львівської області.

О. С. Щур, 2021, с. $37-42$
Витягнена із заходу на схід у формі гострого трикутника 3 розширенням на заході до 60-70 км і звуженням на сході до 5-6 км, вона являє собою пласко-хвилясту акумулятивну й денудаційно-акумулятивну низовину. Поверхня слабо розчленована. Часто трапляються давні денудаційні поверхні й еолові форми рельєфу. Найпоширеніші гірські породи, що виходять на денну поверхню і є грунтотвірними, - верхньокрейдяні мергелі. Велике значення у формуванні рельєфу й антропогенових відкладів мала діяльність текучих вод і розмивних водно-льодовикових потоків, роль яких підсилював неотектонічний рух Подільської плити [12]. Характерним азональним генетичним типом чорноземів Малого Полісся треба вважати залишково-карбонатні чорноземи на елювії щільних карбонатних порід. У наукових працях геодезичного спрямування тему подібних чорноземів майже не розкрито. Деякі відомості про генезис і властивості цих грунтів містяться у двотомному виданні "Грунти України і підвищення їх родючості” (1988), “Польовому визначнику грунтів" (1981), “Атласі грунтів Української РСР” та інших працях. 
Що стосується залишково-карбонатних чорноземів Малого Полісся, то їхні властивості стисло описані в нарисі “Грунти Львівської області” (1969), що пояснює карту грунтів, створену за матеріалами великомасштабних досліджень складу грунтів у 1957-1961 рр. Відтак наукові публікації, присвячені залишково-карбонатним чорноземам на території Малого Полісся, не виходили [13]. Тому вивчення цих грунтів актуальне, має наукове та прикладне значення.

Ознаки та властивості грунтового покриву умовно поділяються на дві основні групи: змінюються впродовж невеликого відтинку часу і змінюються впродовж тривалого періоду. Розмежування між цими двома групами досить умовне, проте можна впевнено стверджувати, що характеристики складу грунту, тісно пов'язані з розміщеними в грунті органічними речовинами, максимально інформативні $з$ погляду вивчення принципів подальшого розвитку грунтів країни. Це зумовлено змінами гідрологічного й біогенетичного характеру, які мають істотне значення для проведення наукових досліджень 3 питань морфологічних особливостей залишково-карбонатних чорноземів на елювії щільних карбонатних порід Малого Полісся і в масштабах всієї країни загалом [14]. Морфологія грунтів різних географічних регіонів важлива для визначення перспектив раціонального використання грунтових угідь та інших дій, спрямованих на вирішення стратегічних питань розвитку народного господарства будь-якої держави. Природні екосистеми, як-от антропогенні та техногенні, характеризуються різноманітними проявами первинних форм утворення грунтів. Їхнє системне вивчення як основних механізмів і способів регенерації грунтових структур має значення як з погляду подальшого розвитку грунтознавства загалом, так і з позиції послідовного розроблення нових методів відновлення грунтів на землях, що зазнали різного руйнівного впливу [7]. 3'ясування особливостей грунтоутворення сприяє швидкому створенню досконалих механізмів керування цим процесом і сприятливо позначається на розвитку грунтів і їхньму якісному використанні в потребах народного господарства країни.

\section{Матеріали та методи}

В основі методології цієї науково-дослідної праці - поєднання методів системного наукового дослідження складу грунтів регіону Малого Полісся загалом, що визначає основні закономірності поширення грунтів у цьому регіоні і їхній морфологічний склад з аналітичним дослідженням морфологічних особливостей залишково-карбонатних чорноземів на елювії щільних карбонатних порід Малого Полісся. Це дає змогу сформувати структуроване наукове дослідження всіх винесених на розгляд питань і чітко окреслити всі актуальні питання проведеного аналізу. Поєднання якісно підібраної теоретичної бази з практичними дослідженнями в зазначеному напрямі сприяє максимально якісному висвітленню всіх винесених на розгляд питань.

Теоретичні аспекти цієї праці грунтуються на вітчизняних і закордонних дослідженнях у сфері особливостей грунтоутворення і вивчення залишково-карбонатних чорноземів на елювії щільних карбонатних порід. Задля максимально якісної, повної і об'єктивної картини наукового дослідження всі дані науково-дослідних розробок іноземних авторів, що згадуються в праці, було перекладено українською мовою. На теоретичній базі наукового дослідження проведено практичні роботи з акцентом на вивчення особливостей залишково-карбонатних чорноземів на елювії щільних карбонатних порід Малого Полісся, що загалом відповідає сформульованим завданням.
Дослідження відбувалося в кілька основних етапів:

1. На першому етапі проведено теоретичне дослідження особливостей грунтоутворення з огляду на специфічні особливості конкретного регіону й морфологічні особливості залишково-карбонатних чорноземів на елювії щільних карбонатних порід загалом. Крім того, системно проаналізовано склад грунтів регіону Малого Полісся, що дало змогу визначити головні закономірності поширення грунтів у цьому регіоні і їхній морфологічний склад.

2. На другому етапі проведено аналітичне дослідження морфологічних особливостей залишково-карбонатних чорноземів на елювії щільних карбонатних порід Малого Полісся, що сприяло розширенню спектра науково-дослідних робіт і поглибленому розумінню досліджуваних аспектів. Також наведено порівняльну характеристику попередніх результатів авторського дослідження й аналогічних за кордоном, що сприяє створенню максимально якісної картини досліджуваної проблеми.

3. На кінцевому етапі наукового дослідження підбито підсумки та сформульовано остаточні висновки щодо всього спектра виконаних науково-дослідних робіт. Результати цього наукового дослідження в майбутньому слугуватимуть якісною основою для проведення подальших наукових досліджень 3 питань, пов'язаних з вивченням морфологічних особливостей залишково-карбонатних чорноземів на елювії щільних карбонатних порід Малого Полісся, а також особливостей утворення й розвитку грунтового покриву в різних регіонах країни.

\section{Результати та обговорення}

У межах Львівської області карбонатні чорноземи займають площу всього 45,7 тис. га (з них 29,6 тис. га - орні землі), або 2,1 \% від площі області. Показник сільськогосподарського освоєння карбонатних чорноземів становить 68,3 \%. Вони сформувалися на плато, схилах і в долинах зовнішніх і внутрішніх пасом, утворилися на вапняках, мергелях і продуктах їхнього вивітрювання, найрізноманітніших за механічним складом. Чорноземи залишково-карбонатні мають загальну потужність щільної частини грунтового профілю 50-80 см, у намитих грунтах - 100 см і більше, а в малопотужних змитих - до 50 см. Потужність щільного горизонту грунту, що має сірий або темно-сірий колір, місцями з коричневим відтінком, коливається в межах 40-60 см. Перехідний горизонт сірий з бурим відтінком або темно-бурий, має неміцну грудкувату структуру. Його потужність становить у середньому 50-70 см. Цим грунтам у верхній частині профілю невластива скелетність, оскільки мергель і мергелястий вапняк м'які породи, що легко піддаються процесам вивітрювання.

Чорноземи залишково-карбонатні характеризуються чималим умістом карбонатів кальцію в межах гумусового горизонту (іноді до 30 \%), кількість якого вниз за профілем збільшується. Особливо багато карбонатів (від 60 до 80 \%) у грунтах, що сформувалися на мергелях. На елювії м'яких порід (мергелях, мергелястих вапняках) швидше відбувається повне перемішування (біологічним або механічним способом) тонкодисперсної карбонатної основи, органічної речовини і силікатної частини породи. У такому разі грунтам властива висока біологічна активність, у них присутня більша кількість грунтових безхребетних (дощових черв'яків та інших представників грунтової мезофауни). Гумус у таких грунтах стає насичений кальцієм і пов'язаний з глиною. Кількість карбонатів у залишково-карбонатних грунтах у перерахунку на $\mathrm{CaCO}_{3}$ коливається в межах 35-55 \%.

За гранулометричним складом залишково-карбонатні чорноземи дуже різноманітні. Серед них трапляються серед- 
ньосуглинкові, високосуглинкові, легкосуглинкові. Морфологічні особливості залишково-карбонатного чорнозему на елювії щільних карбонатних порід Малого Полісся зображено на фото 1. Розріз С-1 закладено на ріллі, за 1 км на схід від с. Заводське Буського району Львівської області. Рельєф - денудаційне акумулятивне плато з нахилом 2х. Ознак затвердіння грунту не спостерігається.

В орному шарі (Hk op. 0-20 см) залишково-карбонатного чорнозему вміст гумусу становить 2 \%. Зверху вниз за профілем уміст гумусу рівномірно зменшується й на глибині 70-80 см становить приблизно 1 \%. Причина цього криється в природі гумусових речовин і розкривається в морфології чорноземів. Горизонт (Hk п/ор. 20-36 см) містить 2,3 \% гумусу, отже в орному шарі за тривалого антропогенного впливу почали переважати процеси деградації та мінералізації. У верхній частині підорного горизонту формується щільний шар грудкувато-брилуватої опрісненої неводостійкої структури. Текстура опріснювальних агрегатів мікросітчаста. Утворення підошви - процес накопичення безпосередньо під орним шаром глини, гумусу й половинчастих оксидів, які тривалий час обробляються на однаковій глибині й водночас постійно зміцнюють орний шар (рисунок).

Структура опрісненого шару залишково-карбонатних чорноземів Малого Полісся на ключовій ділянці с. Заводське (розріз С-1 см - рисунок) брилувата неводостійка. У межах горизонту Hk п/ор. (20-36 см) частка брилуватих (>10 мм) структурних агрегатів становить 87,25 \%, що свідчить про тривале оброблення грунтів досліджуваної території, яке згодом призвело до істотного переущільнення підорного шару. У шарі підорної підошви швидше тривають процеси накопичення гумусу. У межах Малого Полісся перенасиченість підорних шарів залишково-карбонатних чорноземів в окремих випадках виступає головною проблемою деградації грунтового покриву нарівні з процесами дегуміфікації й обвітрювання [15].

Зазвичай на території Малого Полісся залишково-карбонатні чорноземи трапляються в поєднанні з дерново-карбонатними грунтами (рендзини). У місцях близького залягання до денної поверхні щільних порід мож-

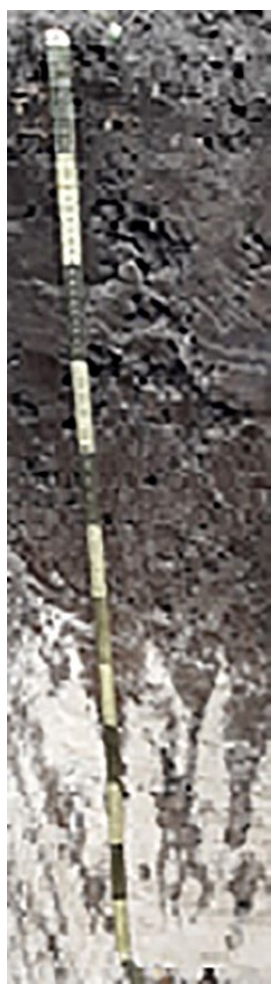
на натрапити на широку гаму грунтів різної потужності (50-110 см) та різної міри розвитку. У поширенні цих грунтів спостерігається певна закономірність: на опуклих ділянках високих елементів мезорельєфу формуються короткопрофільні й малопотужні види чорноземів, гумусова частина профілю яких не перевищує 60-70 см відповідно. Їх нерідко супроводжують не повністю розвинені скелетні грунти, у профілі яких перехідний горизонт слабо виражений або не виражений зовсім, що властиво дерново-карбонатним грунтам [20]. Така мала потужність гумусового горизонту на вершинах схилів зумовлена близьким заляганням щільних порід. Нижче по схилу потужність профілю загалом, зокрема і його щільної частини, поступово зростає, досягаючи в середній частині схилу потужності 70-85 см. У нижній частині схилу і в його підошві формуються глибокі

Фото 1. Ділянка орного чорнозему в розрізі

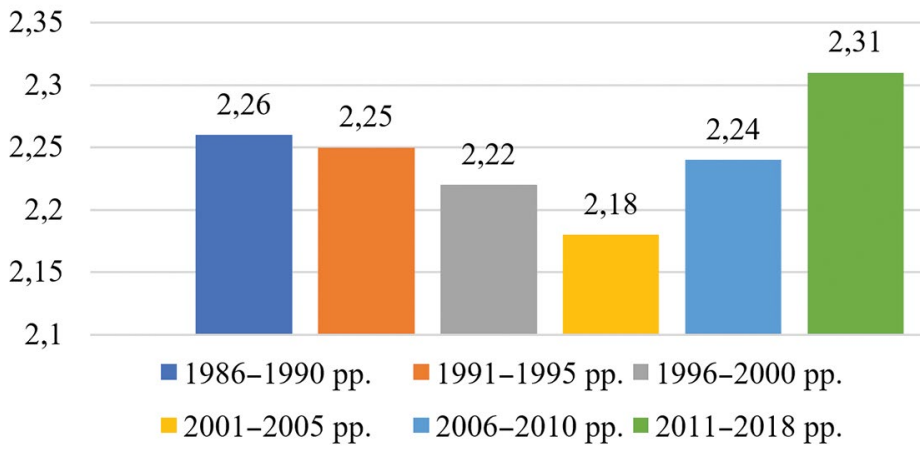

Рисунок. Динаміка вмісту гумусу в грунтах Полісся за 1986-2010 роки, \%

профілі залишково-карбонатних чорноземів, нерідко намиті. Чорноземи на елювії щільних карбонатних порід відрізняються від менш міцної та більш водостійкої зернистої структури у формі дрібного горіха, з гострими ребрами й чіткими гранями структурних частин, - безскелетністю, щільністю та періодом грунтоутворення. Залишково-карбонатні чорноземи, що сформовані на мергелях, менш вилущені, порівнюючи з грунтами, які сформувалися на безкарбонатних породах або лісах.

Отже, морфологічні особливості залишково-карбонатних чорноземів на елювії щільних карбонатних порід Малого Полісся зумовлюються як особливостями рельєфу місцевості в зоні залягання чорноземів, так і особливостями діяльності людини, пов'язаної з обробленням грунтів у цих районах. Структура залишково-карбонатних чорноземів тісно пов'язана 3 кліматичними умовами регіону, з кількістю опадів і показником середньорічної температури [8]. Крім того, чорноземи на елювії щільних карбонатних порід мають високі показники періоду грунтоутворення, що надзвичайно важливо з погляду тривалості експлуатації грунтів і перспектив їхнього подальшого оброблення в сільськогосподарських цілях. Надалі ці показники матимуть істотне значення під час визначення оптимальних умов для оброблення грунту в різних географічних регіонах і створення режиму оброблення сільськогосподарських угідь 3 найбільшою ефективністю 3 погляду родючості грунтів і строків їхньої експлуатаціі.

Питання якісного та ефективного використання орних земель у сільському господарстві мають першорядне значення для сільськогосподарського планування. Водночас треба брати до уваги той факт, що Україна посідає друге місце серед європейських країн за обсягами територій, на яких поширені рендзини (фото 2). Наявна на сьогодні статистична інформація свідчить про те, що саме рендзини в поєднанні з карбонатними чорноземами на елювії карбонатних порід підвищеної щільності охоплюють понад 2 \% орної площі всіх сільськогосподарських земель країни, а це приблизно 1,5 млн га. На західній Україні рендзини й карбонатні чорноземи на елювї щільних карбонатних порід розміщуються на площі понад 162,2 тис. га, або 14,6 \% площі аналогічних грунтів України [2].

Рендзини Малого Полісся - це грунт біолітогенного типу, інтразональний, що пересікається у свойй основі з виходами на поверхню різноманітних побічних продуктів вивітрювання крейдяних порід, а також опоки, мергелів, вапнякових порід, як літотамнієвих, так і хемогенних. Вони дуже поширені в змішаних і широколистих лісах, з гарним рослинним покривом, а також добрими дренажними умовами грунту, зумовленими наявністю промивного й періодично промивного типів зрошувальних режимів, характерних для цієї місцевості [2]. Без- 


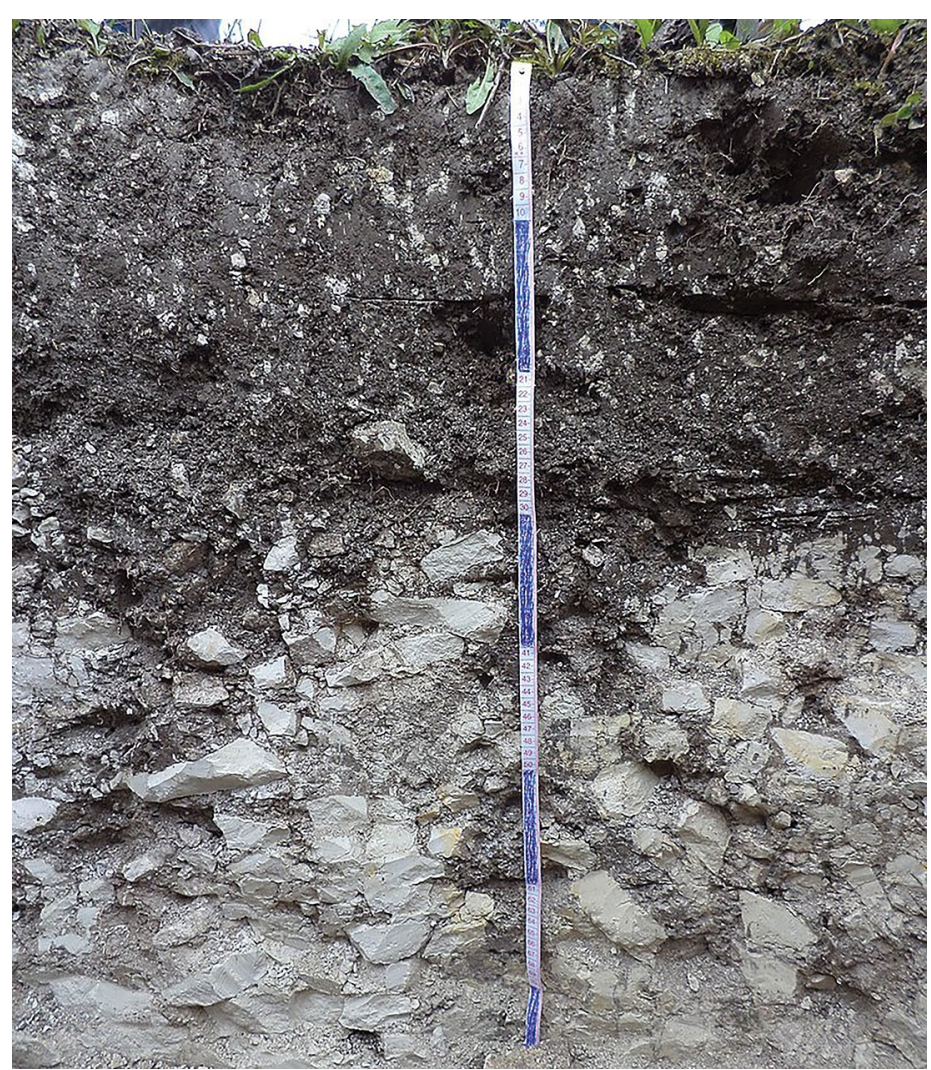

Фото 2. Ділянка дерново-карбонатного грунту (редзини) в розрізі

ліч різноманітних найпростіших за структурою і характером перебігу процесів у шарах грунтів, що протікають в умовах рясного й поступового зволоження, сформували недиференційований (або слабодиференційований) профіль 3 гумусово-акумулятивним горизонтом, збагаченим колоїдами й полуторними оксидами, кількість яких поступово зменшується вниз за профілем, за винятком кальцію, обсяг якого неухильно зростає в зазначеному напрямку. Подібний перерозподіл полуторних оксидів і кальцію загалом типовий для різних стадій перебігу процесу утворення грунтового покриву під деревною рослинністю, що триває паралельно з опідзоленням [5]. Карбонатні літоземи, або типові рендзини, являють собою найпоширеніший тип рендзин на Західній Україні загалом і на Малому Поліссі зокрема. Рендзини вилужені охоплюють набагато меншу площу й характеризуються істотно меншим умістом гумусу й карбонату. Водночас треба брати до уваги, що висока концентрація гумусу й карбонатів у грунтовому горизонті створює всі потрібні умови для підвищення родючості грунтів, росту й подальшого розвитку основних сільськогосподарських культур, які вирощуються в конкретній місцевості. У грунтовій зоні Малого Полісся рендзини заведено зараховувати до розряду найбільш освоєних грунтів, хоча в цьому регіоні майже немає потрібних умов для можливого розширення орних угідь через брак потенційних ресурсів [3].

Рендзини Малого Полісся й усієї Західної України вирізняються високою концентрацією гумусу й карбонатів у зоні верхнього грунтового горизонту, а також наявністю лужної й слаболужної реакції грунту, що загалом сприятливо впливає на стан грунтового покриву, а також майбутнє вирощування основних грунтових культур. Це визначає перспективи подальшого розроблення грунтів Малого Полісся для сільськогосподарського використання та проведення аграрних робіт будь-якого ступеня складності. Масштабне залучення рендзи- ни в сільськогосподарське виробництво поступово призводить до деградації сільськогосподарських грунтових угідь унаслідок істотного зменшення обсягу гумусу в грунті та грунтового виснаження, що виявляється в суттєвому погіршенні якості балансу поживних речовин у шарах грунту [9]. Водночас такі грунти швидше вивітрюються, що істотно зменшує строк їхнього використання й можливості ведення сільськогосподарської діяльності на таких грунтах. Хімічна деградація (декарбонатизація) складу грунтів на тлі істотного погіршення водного й повітряного режимів, за умови фізичної деградації грунтових шарів (дезагрегаціі), з огляду на підвищену ерозію верхніх гумусових горизонтів, поступово призводить до грунтової деградації географічного типу, яка виражається в просторовій нерівномірності течії описуваних процесів у грунтах (фото 3).

Послідовне визначення характеру перебігу процесів агрогенної трансформації грунтових покривів, що належать до сільськогосподарських угідь Західної України й Малого Полісся, дає змогу точно спрогнозувати головні тенденції розвитку грунтів у цих регіонах і відповідно планувати сільськогосподарське використання [18]. Висока консервативність мінерального складу грунтів Малого Полісся зумовлює тенденції розвитку типових процесів грунтоутворення в цьому регіоні, спрогнозувати які можна на підставі хімічного аналізу складу грунтів. Це стосується як реліктових, так і сучасних шарів грунту [6].

Хімічний аналіз грунтових шарів неможливий без спеціальних розрахунків, що уособлюють різні стадії перебігу генетичних процесів, тісно пов'язаних з різними стадіями зміни хімічного складу грунтових шарів у розрізі процесів генезису грунтів та антропогенного впливу на їхній склад. У сучасних умовах послідовне вивчення морфологічних особливостей грунтів, що входять до системи сільськогосподарського комплексу країни, передбачає облік безлічі чинників, важливих 3 погляду оцінювання складу грунту й послідовності зміни його властивостей. У цьому контексті йдеться про зміни мінерального складу грунтового шару, концентрації в грунті гумусу й води, що становить 3 ним хімічний зв'язок, а також про ретельний підрахунок даних [4]. Відсоток сухої маси грунту від загальної маси шару визначається з використанням спеціальних алгоритмів, що дають змогу домогтися високої розрахункової точності та спрогнозувати відсотковий уміст води в грунті на різних стадіях процесу грунтоутворення.

Досить поширені в різних областях Західної України карбонатні грунти характеризуються не тільки накопиченням гумусу у своєму складі, а й розподілом кальцію та

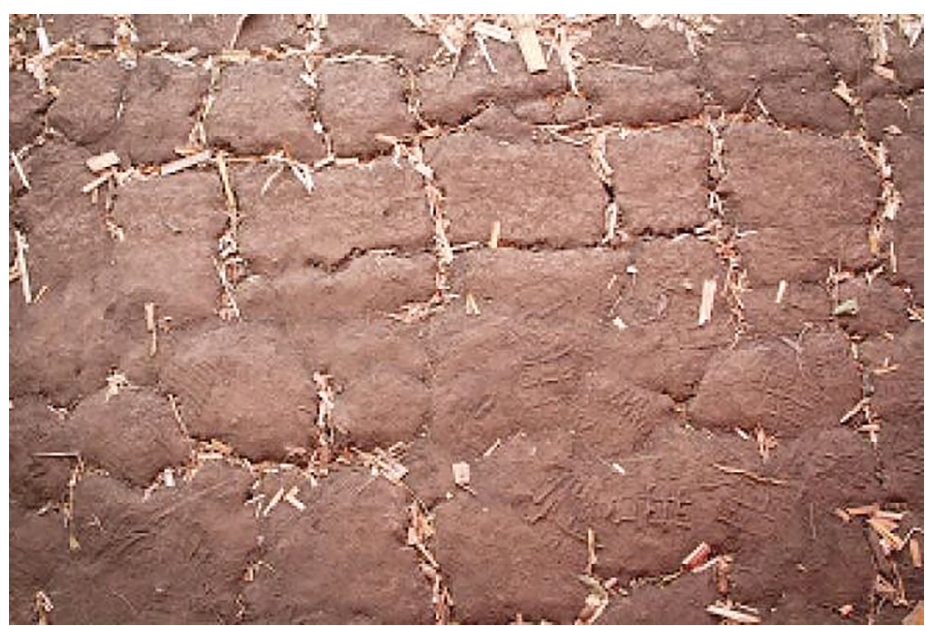

Фото 3. Зразок декарбонатизованого грунту 
інших мінеральних елементів, що впливає на перспективи сільськогосподарського використання грунтів. Акумуляція в грунтових шарах карбонатів кальцію, що мають порівняну рухливість, не завжди дає змогу якісно оцінити ступінь розподілу в профілі грунту мінеральних елементів, зокрема оксидів азоту. 3 цієї причини простеження змін карбонатних грунтів, порівнюючи 3 початковою концентрацією мінеральних елементів, часто потребує одночасного перерахунку показників розпеченого й безкарбонатного грунту. Подібна методика відкриває можливості для аналізування впливу карбонатів і органічних речовин на хімічний склад грунту загалом, що зазвичай дає змогу визначити його фактичну профільну диференціацію [17].

Численні дослідження показують, що послідовне формування та трансформація складу грунту, зокрема рендзини, а також профільний розподіл мінеральних і хімічних елементів у шарах грунту істотно залежать від характеру розподілу карбонатів кальцію, а також винесення їх з грунтових шарів під час вивітрювання. У цьому контексті важливим аспектом також $є$ розчинення і вилуговування карбонатів, що згодом призводить до декарбонізації та збіднення рендзини в основі грунтових шарів низки регіонів країни, оскільки в цьому разі рендзини послідовно виходять зі складу кристалічних граток мінеральних сполук і деяких органічних елементів, розчиняються і зникають 3 профілю грунту. 3 практичного досвіду випливає, що тривале використання рендзини в разі інтенсивних рільницьких робіт поступово призводить до збіднення грунту в умовах інтенсивного вивітрювання грунтових шарів і стає причиною поступового розчинення карбонатів і їхнього вилуговування.

Проведення валового хімічного аналізу дає змогу стверджувати: основу хімічного складу рендзин, дуже поширених на Малому Поліссі й загалом на території Західної України, складають оксиди кремнію $\left(\mathrm{SiO}_{2}\right)$, що характерно майже для всіх частин генетичних профілів цих грунтів. Істотне зниження концентрації $\mathrm{SiO}_{2}$ в напрямку початкової породи, переважно в іï верхній частині, пояснюється послідовним зростанням у цьому напрямку концентрації оксидів кальцію, а також карбонатів кальцію. Подібний перерозподіл концентрації оксидів кальцію і кремнію в основному профілі грунту, особливо в його карбонатній частині, зазвичай пов'язаний $з$ процесами вилуговування карбонатів, що є однією з основних ознак збіднення грунту [17]. Особливості профільного розподілу елементного складу грунту, взятого для дослідження оптимального складу й властивостей показників, припускають високий уміст оксидів заліза й алюмінію, а також лужноземельних елементів. Розподіл оксиду кремнію $\left(\mathrm{SiO}_{2}\right)$ у профілі грунту, а також магнію, кальцію і певної кількості рідкоземельних елементів може бути непрямим свідченням перебігу процесів інтенсивного вивітрювання грунтів, що негативно впливає на їхню родючість і перспективи подальшого використання в сільськогосподарських цілях. Процес поступового вилуговування карбонатів і їхне розчинення - один з неминучих наслідків такого явища.

Хліборобське використання родючих грунтів передбачає створення відповідного грунтового клімату, потрібного для належного використання зазначених земельних угідь. Також треба зважати на істотні відмінності гідротермічних умов використання освоєних орних і цілинних земель, а також вищу водонепроникність ріллі, порівнюючи із цілиною. Орні землі ліпше прогріваються, а також виморожуються в холодну пору року [16]. Забарвлення генетичних горизонтів грунтів дуже залежить від концентрації в них певних оксидів і гідроксидів заліза, водно- час буре забарвлення грунту властиве ділянкам з високою концентрацією оксидів заліза, що характеризуються високим ступенем гідратації. Проведені морфологічні дослідження наочно демонструють той факт, що виразні бурий і буруватий відтінки яскраво проявлені й у низовинах Малого Полісся, до того ж наявна тенденція насичення цих відтінків у напрямку до грунтотвірних порід. Крім того, спостерігається підвищення відносного вмісту $\mathrm{F}_{2} \mathrm{O}_{3}$ в рендзинах згаданого географічного регіону.

Різні показники вилуговування грунтів у різних областях свідчать про нерівномірність перебігу процесів вивітрювання грунтів у цих областях і різні перспективи сільськогосподарської діяльності. Крім того, проведені дослідження акцентують на взаємозв'язку змін морфологічного складу грунтів і показників молярних відносин майже по всій глибині грунтового шару [10]. Визначення тенденції до зміни хімічного складу залишково-карбонатних чорноземів на елювї щільних карбонатних порід Малого Полісся сприяє ліпшому розумінню чинників, що впливають на характер грунтоутворення в зазначеному регіоні, а також пошуку оптимальних рішень, спрямованих на якісне розв'язання питань забезпечення належного збереження орних земель для їхнього подальшого використання в сільськогосподарських цілях.

\section{Висновки}

За результатами, отриманими в процесі наукового дослідження, сформульовано такі висновки. Головним чинником, що забезпечує різноманітність грунтів на території Малого Полісся, є літологія материнських порід (їній гранулометричний склад, глибина залягання й хімічний склад), завдяки чому залишково-карбонатні чорноземи характеризуються хорошими фізико-хімічними й фізичними властивостями. Вивчаючи комплекси дерново-карбонатних і залишково-карбонатних чорноземів, зазначимо, що останні вирізняються безскелетною структурою грунту (у межах гумусового горизонту), високою карбонатністю і глибоким гумусовим профілем в істотній ерозійній небезпеці. Саме небезпека розвитку ерозії грунту визначає потребу проведення комплексних заходів, спрямованих на забезпечення належного рівня захисту грунтового покриву залишково-карбонатних чорноземів Малого Полісся від руйнування і втрати характеристик, потрібних для подальшого використання грунтів цього географічного регіону в сільськогосподарських цілях.

Крім того, результати дослідження акцентують на факті послідовної трансформації хімічного складу залишково-карбонатних чорноземів на елювії щільних карбонатних порід Малого Полісся під впливом зовнішніх кліматичних чинників. Найсильніше на цей процес впливає вилуговування грунтових шарів під дією метеорологічних чинників і сезонних перепадів температури, що передбачає розроблення додаткових заходів захисту грунту від зовнішніх шкідливих впливів. Інтенсивність процесів розчинення карбонатів у різних частинах профілю редзин з їхнім подальшим вилуговуванням безпосередньо визначає швидкість течії вивітрювання грунтового покриву Малого Полісся. Хімічна деградація грунту в регіоні є прямим наслідком процесу.

Процеси деградації грунту негативно впливають на перспективи розвитку сільського господарства. Крім того, залишково-карбонатні чорноземи на елювії щільних карбонатних порід Малого Полісся мають вищі показники водостійкості, порівнюючи з іншими грунтами регіону, що зумовлює вищу тривалість їхнього використання в сільськогосподарських цілях. У будь-якому разі питання захисту грунтів Малого Полісся не втрачають своєї актуальності в сучасних умовах, що передбачає потребу проведення подальших наукових розвідок у цьому напрямі. 


\section{ЛІТЕРАТУРА}

1. Абакумов E. B. Первичные почвы в природных и антропогенных экосистемах: автореф. дис. ... доктора биологических наук. Тольятти: Институт экологии Волжского бассейна Российской академии наук, 2012. - 73 с.

2. Гавриш Н. С. Грунтовые ресурсы и использование грунтов: правовые аспекты//Вестник Международного гуманитарного университета. Серия Юриспруденция. - 2015. - № 15. - С. 76-80.

3. Alsver M. Mycorrhizal mediation of soil. - Oxford: Elsevier, 2019.

4. Baumann K., Eckhardt K-U., Acksel A., Gros P., Glaser K., Gillespie A.W., Karsten U., Leinweber P. Contribution of biological soil crusts to soil organic matter composition and stability in temperate forests//Soil Biology and Biochemistry. - 2021. - Vol.160. - Article number 108315 .

5. Bleam W. Soil and environmental chemistry. - London: Academic Press, 2016.

6. Bossolani J. W., Crusciol C. A. C., Leite M. F. A., Merloti L. F., Moretti L. G., Pascoaloto I. M., Kuramae E. E. Modulation of the soil microbiome by long-term Ca-based soil amendments boosts soil organic carbon and physicochemical quality in a tropical no-till crop rotation system//Soil Biology and Biochemistry. - 2021. - Vol. 156. - Article number 108188 .

7. Dobarco M. R., McBratney A., Minasny B., Malone B. A framework to assess changes in soil condition and capability over large areas// Soil Security. - 2021. - Vol. 4. - Article number 100011.

8. Garcia C., Nannipieri P., Hernandez T. The future of soil carbon.London: Academic Press, 2018.

9. Grover S. P., Butterly C. R., Wang X., Gleeson D. B., Macdonald L. M., Tang $C$. Liming and priming: the long-term impact of $\mathrm{pH}$ amelioration on mineralisation may negate carbon sequestration gains//Soil Security. - 2021. - Vol. 3. - Article number 100007

10. Guo W., Ding J., Wang Q., Yin M., Zhu X., Liu Q., Zhang Z. Yin $H$. Soil fertility controls ectomycorrhizal mycelial traits in alpine forests receiving nitrogen deposition//Soil Biology and Biochemistry. 2021. - Vol. 161. - Article number 108386

11. Jordanova N. Soil magnetism. - London: Academic Press, 2016.

12. Kovda I., Polyakov D., Ryabukha A., Lebedeva M., Khaydarova $D$. Microrelief and spatial heterogeneity of soils on limestone, Sub Ural plateau, Russia: Attributes and mechanism of formation//Soil and Tillage Research. - 2021. - Vol. 209. - Article number 104931.

13. Minasny B., Fiantis D., Hairiah K., Noordmijk M. V. Applying volcanic ash to croplands - The untapped natural solution//Soil Security. - 2021. - Vol. 3. - Article number 100006.

14. Nath D., Laik R., Meena V. S., Pramanick B., Singh S. K. Can mid-infrared (mid-IR) spectroscopy evaluate soil conditions by predicting soil biological properties?//Soil Security. - 2021. - Vol. 4. - Article number 100008 .

15. Nguyen B-A.T., Chen Q-L., Yan Z-Z., Li C., He J-Z., Hu H-W. Distinct factors drive the diversity and composition of protistan consumers and phototrophs in natural soil ecosystems // Soil Biology and Biochemistry. - 2021. - Vol. 160. - Article number 108317.

16. Odriozola I., Navratilova D., Tiaskalova P., Klinerova T., Cervenkova Z., Kohout P., Vetrovsky T., Clizkova P., Stary M., Baldrian P. Predictors of soil fungal biomass and community composition in temperate mountainous forests in Central Europe//Soil Biology and Biochemistry. - 2021. - Vol. 161. - Artice number 108366.

17. Seyfried G. S., Canham C. D., Dalling J. W., Yang W. H. The effects of tree-mycorrhizal type on soil organic matter properties from neighborhood to watershed scales//Soil Biology and Biochemistry. - 2021. Vol. 161. - Article number 108385.

18. Siciliano S. D., Palmer A.S., Winsley T., Lamb E., Bissett A., Brown M. V., van Dorst J., Ji M., Ferrari B. C., Grogan P., Chu H., Snape I. Soil fertility is associated with fungal and bacterial richness, whereas $\mathrm{pH}$ is associated with community composition in polar soil microbial communities//Soil Biology and Biochemistry. - 2019. - Vol. 78. - P. 10-20.

19. Xiong Li., Liu X., Vinci G., Sun B., Drosos M., Li L., Piccolo A., Pan $G$. Aggregate fractions shaped molecular composition change of soil organic matter in a rice paddy under elevated $\mathrm{CO} 2$ and air warming//Soil Biology and Biochemistry. - 2021. - Vol. 159. - Article number 108289 .

20. Zhou Y., Bastida F., Zhou B., Sun Y., Gu T., Li S., Li Y. Soil fertility and crop production are fostered by micro-nano bubble irrigation with associated changes in soil bacterial community//Soil Biology and Biochemistry. - 2020. - Vol. 141. - Article number 107663.

\section{REFERENCES}

1. Abakumov Ye. V. Primary soils in natural and anthropogenic ecosystems: thesis of candidate of biologic sciences. - Tolyatti: Institu Jekologii Volzhskogo basejna Rossijskoj akademii nauk, 2012. - 73 p. (In Russian).

2. Gavrish N. S. Soil resources and soil use: Legal aspects//Vestnik Mezhdunarodnogo gumanitarnogo universiteta. Seriya Jurisprudenciya. - 2015. - № 15. - P. 76-80. (In Russian).

3. Alsver M. Mycorrhizal mediation of soil. - Oxford: Elsevier, 2019.

4. Baumann K., Eckhardt K-U., Acksel A., Gros P., Glaser K., Gillespie A. W., Karsten U., Leinweber P. Contribution of biological soil crusts to soil organic matter composition and stability in temperate forests//Soil Biology and Biochemistry. - 2021. - Vol. 160. - Article number 108315.

5. Bleam W. Soil and environmental chemistry. - London: Academic Press, 2016.

6. Bossolani J. W., Crusciol C. A. C., Leite M.F.A., Merloti L.F., Moretti L. G., Pascoaloto I. M., Kuramae E. E. Modulation of the soil microbiome by long-term Ca-based soil amendments boosts soil organic carbon and physicochemical quality in a tropical no-till crop rotation system//Soil Biology and Biochemistry. - 2021. - Vol. 156. - Article number 108188 .

7. Dobarco M. R., McBratney A., Minasny B., Malone B. A framework to assess changes in soil condition and capability over large areas// Soil Security. - 2021. - Vol. 4. - Article number 100011.

8. Garcia C., Nannipieri P., Hernandez T. The future of soil carbon.London: Academic Press, 2018.

9. Grover S. P., Butterly C. R., Wang X., Gleeson D. B., Macdonald L. M., Tang $C$. Liming and priming: the long-term impact of $\mathrm{pH}$ amelioration on mineralisation may negate carbon sequestration gains//Soil Security. - 2021. - Vol. 3. - Article number 100007.

10. Guo W., Ding J., Wang Q., Yin M., Zhu X., Liu Q., Zhang Z., Yin $H$. Soil fertility controls ectomycorrhizal mycelial traits in alpine forests receiving nitrogen deposition//Soil Biology and Biochemistry. 2021. - Vol. 161. - Article number 108386.

11. Jordanova N. Soil magnetism. - London: Academic Press, 2016.

12. Kovda I., Polyakov D., Ryabukha A., Lebedeva M., Khaydarova $D$. Microrelief and spatial heterogeneity of soils on limestone, Sub Ural plateau, Russia: Attributes and mechanism of formation//Soil and Tillage Research. - 2021. - Vol. 209. - Article number 104931.

13. Minasny B., Fiantis D., Hairiah K., Noordmijk M.V. Applying volcanic ash to croplands - The untapped natural solution//Soil Security. - 2021. - Vol. 3. - Article number 100006.

14. Nath D., Laik R., Meena V. S., Pramanick B., Singh S. K. Can mid-infrared (mid-IR) spectroscopy evaluate soil conditions by predicting soil biological properties?//Soil Security. - 2021. - Vol. 4. - Article number 100008

15. Nguyen B-A.T., Chen Q-L., Yan Z-Z., Li C., He J-Z., Hu H-W. Distinct factors drive the diversity and composition of protistan consumers and phototrophs in natural soil ecosystems // Soil Biology and Biochemistry. - 2021. - Vol. 160. - Article number 108317.

16. Odriozola I., Navratilova D., Tiaskalova P., Klinerova T., Cervenkova Z., Kohout P., Vetrovsky T., Clizkova P., Stary M., Baldrian P. Predictors of soil fungal biomass and community composition in temperate mountainous forests in Central Europe//Soil Biology and Biochemistry. - 2021. - Vol. 161. - Artice number 108366.

17. Seyfried G. S., Canham C. D., Dalling J. W., Yang W. H. The effects of tree-mycorrhizal type on soil organic matter properties from neighborhood to watershed scales//Soil Biology and Biochemistry. - 2021. Vol. 161. - Article number 108385

18. Siciliano S. D., Palmer A. S., Winsley T., Lamb E., Bissett A., Brown M. V., van Dorst J., Ji M., Ferrari B. C., Grogan P., Chu H., Snape I. Soil fertility is associated with fungal and bacterial richness, whereas $\mathrm{pH}$ is associated with community composition in polar soil microbial communities//Soil Biology and Biochemistry. - 2019. - Vol. 78. - P. 10-20.

19. Xiong Li., Liu X., Vinci G., Sun B., Drosos M., Li L., Piccolo A., Pan $G$. Aggregate fractions shaped molecular composition change of soil organic matter in a rice paddy under elevated $\mathrm{CO} 2$ and air warming//Soil Biology and Biochemistry. - 2021. - Vol. 159. - Article number 108289.

20. Zhou Y., Bastida F., Zhou B., Sun Y., Gu T., Li S., Li Y. Soil fertility and crop production are fostered by micro-nano bubble irrigation with associated changes in soil bacterial community//Soil Biology and Biochemistry. - 2020. - Vol. 141. - Article number 107663.

Рукопи с о тримано 5.10 .2021$. 